\title{
KEPATUHAN SYARIAH PADA PRODUK MUSHARAKAH DI BANK SYARIAH INDONESIA
}

\author{
Sujian Suretno \\ Dosen STAI al-Hidayah Bogor
}

\begin{abstract}
This article assesses whether or not the syari ah bank is in its practice similar to the conventional one. This study uncovers that these two types of bank have some similarities in their practices of financing cooperations either in terms of their procedures, their administrations, and their principles.
\end{abstract}

Keywords: Syariah, syuro, sunni, khilafah

\section{A. Pendahuluan}

Terjadinya kesenjangan ekspektasi kaum muslimin terhadap bank syariah masih sangat dirasakan. ${ }^{1}$ Hal itu tercermin dari sebuah pertanyaan yang sampai saat ini masih belum ditemukan jawaban pastinya. Pertanyaan itu adalah, "Apakah bank syariah itu pada praktiknya sama dengan bank konvensional?" 2 Pertanyaan itu muncul karena dalam beberapa kasus, nasabah banyak menemukan kesamaan yang terjadi antara bank syariah dengan bank konvensional dalam praktik kerjasama pembiayaan. Kesimpulan sederhana ini wajar dirasakan oleh masyarakat, karena sebelumnya mereka telah terbiasa bekerjasama dengan bank konvensional dalam penyaluran kredit.

Kesamaan itu ada yang bersifat prosuderal, administratif, maupun prinsipil. Yang bersifat prosedural misalkan bahwa syarat-syarat yang harus dipenuhi pada permohonan pembiayaan bank syariah sama dengan syaratsyarat yang harus dipenuhi pada permohonan kredit bank konvensional,

\footnotetext{
${ }^{1}$ Muhammad Nizarul Alim, Muhasabah Keuangan Syariah, (Solo: Aqwam Media Profetika, 2011), 95.

${ }^{2}$ http://www.rumahfiqih.com/x.php?id=1383143419, Konsultasi Fiqh, Ustadz, Ahmad Sawat, Lc. MA, Bank Syariah Sama Saja Dengan Bank Konvensional, Benarkah?, Mon 4 November 2013 01:40 | muamalat | 62.680 views, diunduh hari Sabtu, 11 Juni 2016. Pertanyaan senada: http://kmi-s.ppisendai.org/bank-syariah/, Bank Syariah: Apakah Benarbenar Syar'i?, Muhammad Rifqi, diunduh hari Sabtu, 11 Juni 2016. http://noven-suprayogifeb.web.unair.ac.id, Samakah Bank Syariah dengan Bank Konvensional?, 30 January 2013 dalam Perbankan Syariah Oleh noven-suprayogi-feb,
} 
seperti disyaratkannya dokumen dan legalitas penting yang dibutuhan. ${ }^{3}$ Kemudian diperlukannya jaminan yang cukup untuk meng-cover pembiayaan. Selain itu bank syariah juga menerapkan analisa kredit five $C^{\prime} s$ terhadap proposal permohonan pembiayaan nasabah yang didasarkan pada tingkat kolektibilitas nasabah ${ }^{4}$ (tingkat kemampuan nasabah dalam mengangsur kewajibannya), dan seterusnya.

Hal-hal tersebut di atas merupakan persoalan teknis prosedural yang tentunya tidak bertentangan dengan syariat Islam. Adapun yang bersifat administrasi juga terjadi pada bank syariah, misalnya pada pembiayaan modal kerja, bank syariah juga mensyaratkan biaya administrasi kepada nasabah, hanya saja hal ini sedikit berbeda dengan bank konvensional. Pada bank syariah jumlah biaya administrasi yang ditetapkan berdasarkan perkiraan angka humanis ${ }^{5}$, Bank syariah menganggap wajar mensyaratkan biaya administrasi tersebut untuk setiap proses pembiayaan. Atau hal ini sama dengan ujrah atau upah pegawai/jasa manajemen yang telah menyediakan seluruh sarana administrasi yang dibutuhkan untuk menunjang pembiayaan, sebagai bahan referensi kedua belah pihak untuk menerapkan praktik pembiayaan agar tidak terjadi perselisihan di kemudian hari. Pada bank konvensional juga disyaratkan biaya administrasi berdasarkan persentase dari total dana kredit yang diberikan. Kemudian pada hal yang bersifat prinsipil juga ditemukan kesamaan, misalnya bank syariah menetapkan bagi hasil kepada nasabah dengan nisbah tertentu yang bersifat tetap selama masa tenor perjanjian.

Hal ini hampir mirip dengan praktik pembungaan penyaluran kredit pada bank konvensional. Kemudian bank syariah juga menerapkan penalti bagi nasabah yang terlambat membayar angsuran, hal ini juga hampir sama dengan pemberlakuan denda keterlambatan pada kredit bank konvensional, perbedaannya pemberlakuan penalti pada bank syariah ini sebagai bentuk hukuman kepada nasabah yang terlambat membayar angsuran, dan seluruh dana penalti yang diterima tidak menjadi income (pendapatan) bank syariah, tetapi dimasukkan ke dalam penerimaan dana non halal ${ }^{6}$ atau yang dikenal

\footnotetext{
${ }^{3}$ http://www.bnisyariah.co.id/produk/bni-syariah-wirausaha, Syarat Permohonan Pembiayaan, diunduh hari Sabtu, 11 Juni 2016.

${ }^{4} \mathrm{http} / / /$ bramnugra.com/mengenal-bi-checking-penggolongan-kolektibilitas-kredit-dibank-indonesia/, Mengenal BI Checking, penggolongan kolektibilitas kredit di Bank Indonesia, diunduh hari Sabtu, 11 Juni 2016.

${ }^{5}$ http://kbbi.web.id/humanis, humanis/hu·ma.nis/ orang yang mendambakan dan memperjuangkan terwujudnya pergaulan hidup yang lebih baik, berdasarkan asas perikemanusiaan; pengabdi kepentingan sesama umat manusia; 2 penganut paham yang menganggap manusia sebagai objek terpenting; 3 penganut humanisme, diunduh pada hari Sabtu, 11 Juni 2016.

${ }^{6} \mathrm{http}: / /$ mysharing.co/dana-non-halal-untuk-fikih-islam/, Pengelolaan Dana Non Halal untuk Pemberdayaan Masyarakat Menurut Fikih Islam, by Ibrahim Aji on 20/08/2014, diunduh hari Sabtu, 11 Juni 2016.
} 
dengan dana ta' $z \bar{\imath} r$ yang dana itu akan disalurkan kepada fakir miskin dan orang-orang yang membutuhkan, sesuai dengan fatwa DSN-MUI ${ }^{7}$. Sedangkan biaya denda pada bank konvensional menjadi salah satu pos pendapatan bank tersebut.

Selanjutnya dalam sistem perhitungan bagi hasil yang diterapakan oleh bank syariah hampir sama dengan sistem bunga yang diterapkan pada bank konvensional, dimana bank syariah menerapkan sistem bagi hasil dengan menggunakan metode revenue sharing, ${ }^{8}$ yaitu bagi hasil yang diambil dari persentase total pendapatan usaha nasabah yang meliputi total modal dan total keuntungan tanpa dikurangi biaya-biaya. Bagi hasil model revenue sharing cenderung merugikan nasabah (pengelola dana dalam berbagai usaha produktif) ${ }^{9}$, karena tidak didasarkan pada keuntungan dan kerugian yang terjadi pada usaha pengelola. Jadi apabila pengelola usaha mengalami kerugian, maka ia tetap harus membayar bagi hasil sesuai dengan kesepakatan di awal perjanjian. Revenue sharing merupakan salah satu metode bagi hasil yang kontroversial, karena bertentangan dengan sistem bagi hasil profit and loss sharing yang lebih rasional dan berasaskan keadilan. Bagi hasil pada profit and loss sharing didasarkan pada keuntungan dan kerugian, kemudian nisbah yang ditetapkan di awal sama dengan jumlah kontribusi dana yang ditempatkan oleh kedua belah pihak dalam modal usaha, demikian juga bila terjadi kerugian, maka kedua belah pihak baik bank syariah maupun pengelola usaha sama-sama menanggung kerugian berdasarkan porsi kontribusi dana masing-masing yang ditempatkan dalam modal usaha. Apabila keuntungan proyek besar maka nilai bagi hasil yang diperoleh juga besar, apabila keuntungan proyek kecil maka nilai bagi hasilpun juga kecil. ${ }^{10}$

Dengan demikian dapat disimpulkan bahwa sistem bagi hasil profit and loss sharing lebih memberikan rasa keadilan dan ketentraman bagi bank syariah dan pengelola usaha. Sedangkan sistem bagi hasil dengan metode

\footnotetext{
${ }^{7}$ Fatwa Dewan Syari'ah Nasional Nomor 54/DSN-MUI/X/2006 Tentang Syariah Card.

${ }^{8}$ Revenue sharing adalah perhitungan bagi hasil didasarkan kepada total seluruh pendapatan yang diterima sebelum dikurangi biaya-biaya yang telah dikeluarkan untuk memperoleh pendaptan tersebut. Profit Sharing adalah perhitungan bagi hasil didasarkan kepada hasil net dari total pendapatan setelah dikurangi biaya-biaya yang dikeluarkan untuk memperoleh pendapatan tersebut. Muhamad, Teknik Perhitungan Bagi Hasil dan Pricing di Bank Syariah, (Yogyakarta: UUI Press, 2012), 97.

${ }^{9}$ Mervin K. Lewis - Latifa M. Algaoud, Perbankan Syariah, Prinsip, Praktik, dan Prospek, (Jakarta: Serambi, 2007), Cet. 1, 16.

${ }^{10}$ Sunarto Zulkifli, Panduan Praktis Transaksi Perbankan Syariah, (Jakarta: Zikrul, 2007), 79. Menjelaskan bahwa pada skim mushärakah, bank syariah dan nasabah sama-sama memiliki kontribusi dana dalam usaha. Pengembalian hasil usaha tergantung kepada nisbah bagi hasil yang disepakati nasabah dan bank syariah. Semakin tinggi kinerja nasabah, semakin tinggi pula bagi hasil untuk masing-masing pihak.
} 
revenue sharing dalam praktiknya hampir sama, atau minimal mirip dengan praktik bunga (menetapkan expected rate bank atas dasar kesepakatan/keridhaan kedua belah pihak $)^{11}$ pada bank syariah yang cenderung mengandung unsur riba. ${ }^{12}$ Kemudian penanganan pembiayaan bermasalah pada bank syariah ternyata juga sama yang terjadi pada bank konvensional, hal ini dapat dilihat dalam PBI No. 10/18/PBI/2008 ${ }^{13}$ tentang Restrukturisasi Pembiayaan Bagi Bank Umum Syariah dan Unit Usaha Syariah. ${ }^{14}$ Nah hal inilah yang akhirnya menimbulkan keraguan dan kegelisahan kaum muslimin terhadap bank syariah.

Karena larangan riba ${ }^{15}$ merupakan sesuatu yang thawābit (principles) ${ }^{16}$, bukan sesuatu yang mutaghayyirāt (variables) dalam Islam. Secara teknis riba adalah nilai tambah dari pokok pinjaman yang disesuaikan dengan jangka waktu dan jumlah pinjaman. ${ }^{17}$ Artinya bahwa larangan riba tersebut bersifat mutlak dan tidak akan berubah sampai hari kiamat. Dalam Islam larangan riba

${ }^{11}$ Wāhid Abd al-Salam Bāli, Dialog Ilmiah Bank Syariah Vs Bank Konvensional, (Jakarta: Darul Falah, 2002), 29. Menjelaskan bahwa keridhaan tidak dapat menghalalkan yang haram dan mengharamkan yang halal, karena sudah ada ketetaapan dalil-dalil yang shahih dalam Alquran dan al-Sunnah serta Ijmā' bahwa tambahan yang disyaratkan terhadap harta pokok ketika terjadi transaksi pinjam meminjam, dianggap riba yang diharamkan menurut syariat.

${ }^{12}$ The prohibition of riba means that any predetermined payment over and above the actual amount of principal is prohibited (usually interpreted as usury or interest). Sana N. Maswadeh, "A Compliance of Islamic Banks with The Principles Of Islamic Finance (Shariah): An Empirical Survey Of The Jordanian Business Firms", International Journal of Accounting and Financial Reporting, (2014), Vol. 4, No.1, 171.

${ }^{13}$ PBI No. 10/18/PBI/2008 Tentang Restrukturisasi Pembiayaan Bagi Bank Umum Syariah dan Unit Usaha Syariah, 5.

${ }^{14}$ Khotibul Umam, Perbankan Syariah, Dasar-dasar dan Dinamika Perkembangannya di Indonesia, (Jakarta: Raja Grafindo Persada, 2016), 209.

${ }^{15}$ Riba di dalam bahasa Arab berarti "bertambah" maka segala sesuatu yang bertambah dinamakan riba. Menurut istilah, riba berarti: menambahkan beban kepada pihak yang berutang (dikenal dengan riba dayn) atau menambahkan takaran saat melakukan tukar menukar 6 komoditi (emas, perak, gandum, sya'ir, kurma dan garam) dengan jenis yang sama, atau tukar menukar emas dengan perak dan makanan dengan makanan dengan cara tidak tunai (dikenal dengan riba ba'i). Erwandi Tarmidzi, Harta Haram Muamalat Kontemporer, (Bogor: Berkat Mulia Insani, 2015), Cet. 9, 335. Istilah riba telah dikenal dan digunakan dalam transaksitransaksi perekonomian oleh masyarakat Arab sebelum datangnya Islam. Akan tetapi pada zaman itu riba yang berlaku adalah merupakan tambahan dalam bentuk uang akibat penundaan pelunasan utang. Dengan demikian, riba dapat diartikan sebagai pengambilan tambahan dalam transaksi jual beli maupun utang piutang secara batil atau bertentangan dengan kaidah syari'at Islam. Wasilul Choir, "Riba dalam Perspektif Islam", Iqtishadia, (2014), Vol. 1, No.1, 6.

${ }^{16}$ Muhammad Syafii Antonio, Bank Syariah dari Teori ke Praktik, (Depok: Gema Insani-Tazkia Cendekia, 2015), 5.

${ }^{17}$ Mervin K. Lewis - Latifa M. Algaoud, Perbankan Syariah, Prinsip, Praktik, dan Prospek, (Jakarta: Serambi, 2007), Cet.1, 17.

4 | INDO-ISLAMIKA, Volume 9 No.1 Januari-Juni 2019/1440 
sama dengan larangan zina, mencuri, berbuat zalim, membunuh dan lain sebagainya. Dan larangan-larangan ini merupakan tujuan syariah atau maqāșid al-sharī'ah ${ }^{18}$ yaitu perlindungan terhadap jiwa, harta, agama, kehormatan, keturunan, dan akal. Dan salah satu maqūșid al-sharì'ah itu adalah perlindungan terhadap harta benda, unsur darüriyyāt dalam hal ini adalah kepemilikan harta sesuai dengan aturan syariat. Islam telah mengatur secara ketat dan komprehensif tentang masalah harta ini dengan tujuan-tujuan yang sangat mulia. Karena tentang harta ini kelak manusia akan ditanyai tentang dua hal: (1) dari mana ia mendapatkannya, (2) dan dibelanjakan untuk apa. Rasulullah șallallāhu 'alaihi wa sallam bersabda,

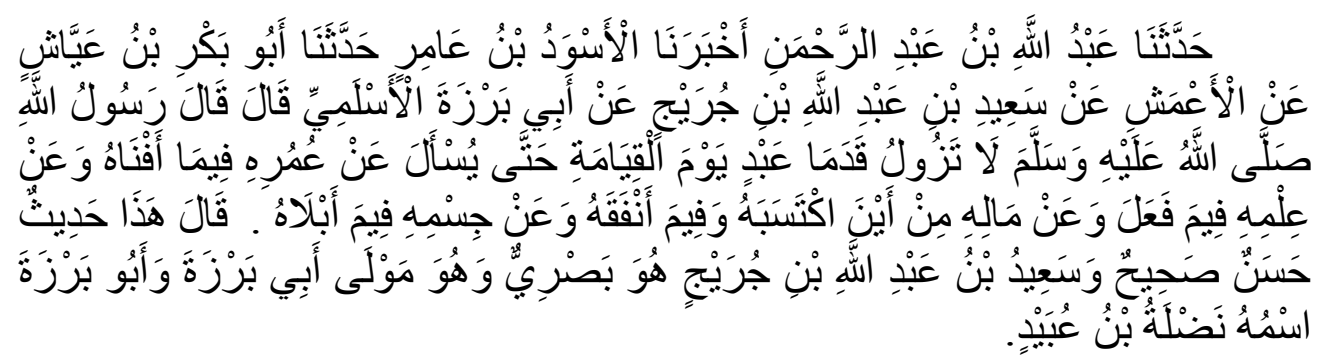

Telah menceritakan kepada kami Abd Allāh ibn Abd al-Raḥmān telah menceritakan kepada kami al-Aswad ibn 'Āmir telah mengabarkan kepada kami Abū Bakr ibn Ayyash dari al-A'mashi dari Sa'īd ibn Abdullāh ibn Juraij dari Abī Barzah al-Aslamī berkata: Rasulullah șallallāhu 'alaihi wa sallam bersabda: "Kedua telapak kaki seorang hamba tidak akan bergeser pada hari kiamat sampai ditanya tentang umurnya untuk apa dia habiskan, tentang ilmunya untuk apa dia amalkan, tentang hartanya dari mana dia peroleh dan kemana dia nafkahkan dan tentang tubuhnya untuk apa dia gunakan." Dia berkata: Hadis ini ḥasan șahīh, adapun Sa ‘īd ibn Abdullāh ibn Juraij dia adalah orang Bașrah dan dia adalah budak Abū Barzah, sedangkan Abū Barzah namanya adalah Naḍlah ibn 'Ubaid. Diriwayatkan dari sahabat Abū Barzah al-Aslamī radiyallāhu 'anhu. ${ }^{19}$

Tentunya ini merupakan dua pertanyaan yang sangat berat untuk dijawab manakala seseorang itu mendapatkan harta itu dengan jalan yang haram dan dibelanjakan untuk sesuatu yang haram pula atau sesuatu yang tidak jelas. Namun hal ini berbeda dengan seseorang yang memperoleh harta dengan cara yang halal dan dibelanjakan untuk kebutuhan yang diperbolehkan oleh syar'i, tentu hal ini akan lebih menentramkan dan memberikan

${ }^{18}$ Ahmad Al-Mursi Husain Jauhar, Maqāsid al-Sharī'ah, (Jakarta: Sinar Grafika Offset, 2010), 167.

${ }^{19} \mathrm{Abū}$ 'Īsā Muhammad Ibn 'Īsā al-Tirmidhī, Jāmi ' al-Tirmidhī, Kitāb șifāt al-Qiyāmah wa al-Raqāiq wa al-Wara‘, Bāb fì al-Qiyāmah, (Riyāḍ: Dār al-Salām Li al-Nashri wa alTauzī‘i, 1999), Nomor Hadīth 2417, 551. 
ketenangan pada hati dan jiwa manusia. Selain itu harta merupakan ujian, seorang muslim tidak boleh menumpuk-numpuk harta atau menghamburhamburkannya untuk hal yang sia-sia. ${ }^{20}$ Allah subḥānahu wa ta 'āla berfirman,

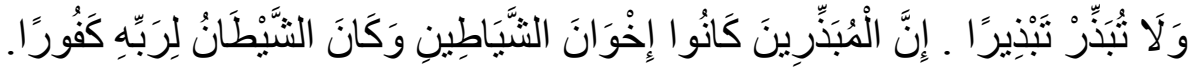

"Dan janganlah kamu menghambur-hamburkan (hartamu) secara boros. Sesungguhnya pemboros-pemboros itu adalah saudara-saudara syaitan dan syaitan itu adalah sangat ingkar kepada Tuhannya."

Dalam harta itu juga terdapat hak-hak yang harus dipenuhi, seperti zakat, infak, dan sedekah ${ }^{21}$ yang harus dikeluarkan untuk orang-orang yang membutuhkan sesuai aturan syariat. Allah subhānahu wa ta 'āla berfirman:

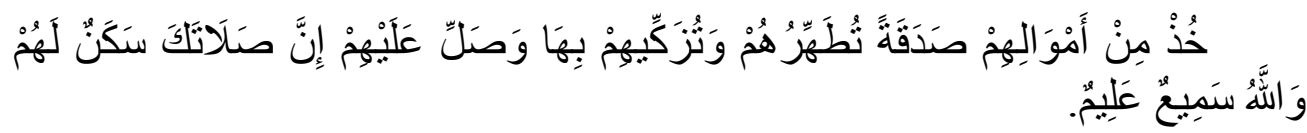

"Ambillah zakat dari sebagian harta mereka, dengan zakat itu kamu membersihkan dan mensucikan mereka dan mendoalah untuk mereka. Sesungguhnya doa kamu itu (menjadi) ketenteraman jiwa bagi mereka. Dan Allah Maha Mendengar lagi Maha Mengetahui."

Untuk itu penulis menegaskan kembali bahwa riba itu haram, dan sesuatu yang haram dan halal telah jelas aturannya dalam Islam. ${ }^{22}$ Rasulullah șallallāhu 'alaihi wa sallam, bersabda dalam sebuah haditsnya;

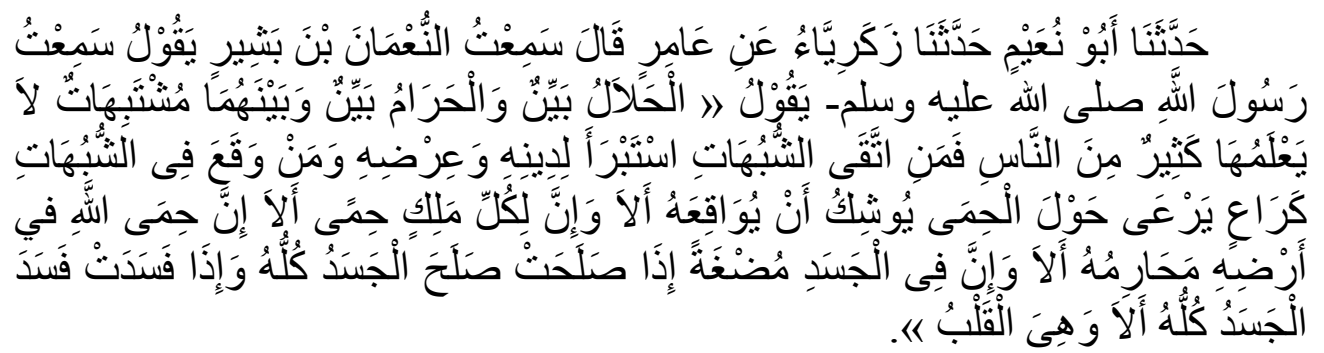

Telah meriwatkan kepada kami Abū Nu'aim, telah meriwayatkan kepada kami Zakariyya dari 'Āmir beliau berkata aku mendengar al-Nu'mān Ibn Bashīr beliau berkata saya mendengar Rasulullah bersabda: "Sesungguhnya segala perkara yang halal itu jelas, dan perkara yang haram

${ }^{20}$ QS. al-Isrā' [17]: 26-27.

${ }^{21}$ QS. al-Tawbah [9]: 103.

${ }^{22}$ http://www.al-ahkam.net/home/hadīth-40/hadīth-40-06-sesungguhnya-yang-halalitu-jelas-dan-yang-haram-itu-jelas, Hadìth 40: 06. Sesungguhnya yang halal itu jelas dan yang haram itu jelas, diunduh hari Sabtu, 11 Juni 2016.

6 | INDO-ISLAMIKA, Volume 9 No.1 Januari-Juni 2019/1440 
itu jelas. Dan di antara keduanya ada perkara yang samar-samar yang kebanyakan manusia tidak mengetahuinya. Siapa yang menjauhi dirinya dari perkara yang samar tersebut, sungguh ia telah berlepas diri untuk menjaga keselamatan agama dan kehormatannya. Dan siapa yang jatuh ke dalam perkara yang syubhat, ia seperti penggembala yang menggembalakan hewan gembalaannya di area terlarang, yang hampir saja memasukinya. Ketahuilah bahwa setiap pemimpin mempunyai wilayah yang terlarang. Ketahuilah sesungguhnya wilayah terlarang Allah di muka bumi ini ada pada apa yang diharamkan-Nya. Sesungguhnya dalam jasad terdapat segumpal daging, yang apabila segumpal daging itu baik maka baik pula jasadnya, dan jika segumpal daging itu buruk maka buruk pula jasadnya, ketahuilah bahwa segumpal daging itu adalah hati." Diriwayatkan dari Sahabat al-Nu 'mān Ibn Bashīr oleh Abū Abd Allāh Muhammad Ibn Ismā‘̄il al-Bukhārî. ${ }^{23}$

Hadis ini menjelaskan bahwa yang haram telah jelas dan yang haram juga telah jelas. Perkara-perkara yang haram termasuk riba di dalamnya merupakan perkara yang sudah final dan tidak perlu diperdebatkan lagi. Larangan dari Allah tersebut harus diimani dengan benar.

Riba merupakan dosa besar yang termasuk dalam tujuh kategori dosa besar yang membinasakan. Besarnya dosa riba diukur dari kadar perbuatan riba yang paling ringan saja, seperti seorang laki-laki yang menzinahi ibu kandungnya sendiri. Dan besarnya dosa riba juga dapat diukur dari golongan dosa-dosa besar yang lainnya seperti syirik kepada Allah, sihir, membunuh jiwa yang diharamkan Allah tanpa hak, memakan harta anak yatim, lari dari medan perang dan menuduh seorang wanita mukmin yang suci berzina. Dampak riba bagi pelakunya sangatlah berat, di dunia hartanya akan dimusnahkan ${ }^{24}$ dan di akhirat kelak ia akan disiksa dengan siksaan yang sangat pedih di neraka jahannam. Allah subḥānahu wa ta 'āla berfirman,

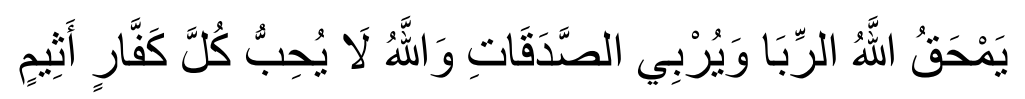

"Allah memusnahkan riba dan menyuburkan sedekah. Dan Allah tidak menyukai setiap orang yang tetap dalam kekafiran, dan selalu berbuat dosa."

Kemudian riba juga berdampak pada kehidupan bermasyarakat. Banyak masyarakat yang terjerumus pada riba seperti budaya utang, kredit konsumtif, kredit barang mewah dan lain-lain, sehingga penyakit sosial yang timbul akibat riba di masyarakat semakin meluas dan sangat mengkhawatirkan,

${ }^{23}$ Abū Abdillāh Muhammad Ibn Ismā 'îl al-Bukhārī, Șaḥ̄ḥ al-Bukhārī, Kitāo al-Īmān, Bāb Faḍlu Man-Istabra'a li Dīnihī, (Kairo: Dār al-Ghad al-Jadīd, 2009), Nomor Hadīth 52, 21. Dan juga dalam Kitāb al-Buyū‘, Bāb al-Ḥalālu Bayyinun wal Harāmu Bayyinun wa Bainahumā Mushtabihāt, Nomor Ḥadīth 2051, 371. Derajat ḥadīth ṣahịḥ̣.

${ }^{24}$ QS. al-Baqarah [2]: 276. 
seperti maraknya pencurian, pembunuhan, penodongan dan lain-lain yang berakibat hilangnya rasa aman di masyarakat. Dan riba juga berdampak pada perekonomian suatu negara seperti krisis ekonomi global, realita inflasi yang sangat ekstrim dan terjadi secara terus menerus sehingga sangat sulit untuk dikendalikan, dan lain-lain. Artinya bahwa sebanyak apapun harta yang dimiliki oleh seseorang yang terkena riba itu akan musnah, akan lenyap karena Allah subhāanahu wa ta'āla sendiri yang akan melenyapkannya. Selain itu bahwa harta yang haram dapat membinasakan manusia itu sendiri. Oleh karena itu pemahaman terhadap riba dan bahayanya harus menjadi prinsip bagi seorang muslim.

Bank syariah harus memiliki keberanian yang kuat, untuk menyatakan bahwa seluruh kegiatan usaha yang dilakukan baik dalam bentuk produk, jasa dan berbagai akad pembiayaan benar-benar terbebas dan bersih dari riba. Bahkan bank syariah sendiri harus berani mempublikasikan secara terangterangan tentang seluruh produk jasa dan akad pembiayaan kepada masyarakat. Sehingga masyarakat dapat mempelajarinya terlebih dahulu atau mengkonsultasikannya kepada para ulama yang ahli di bidang tersebut. Tentu ini merupakan sebuah upaya yang sangat fair dan terbuka. Sehingga apabila terdapat hal-hal yang tidak sesuai dengan syar'i, maka para nasabah dapat memberikan masukan kepada bank syariah. Karena ini merupakan bagian dari dakwah yaitu saling nasihat dan menasihati dalam kebenaran. Sarana untuk saling memeberi kritik yang konstruktif, masukan yang berharga, ide yang bagus, atau solusi yang tepat harus dibuka lebar-lebar sebagai alat kontrol dan pengawasan yang bersifat efektif dari saudara sesama muslim.

Esensi bank syariah harus memiliki warna yang kontras dengan bank konvensional. Artinya bank syariah harus benar-benar dapat meyakinkan kepada kaum muslimin bahwa bank syariah bebas riba dan transaksi-transaksi yang mengarah pada riba, baik dalam akad maupun produk syariahnya. Bank syariah harus menjadi pilihan bukan alternatif bagi kaum muslimin. Karena pada hakikatnya apabila sudah ada bank yang syar'i dan bebas dari riba, maka kaum muslimin wajib untuk berhijrah dari bank konvensional ke bank syariah. Hal ini menjadi penting agar bank syariah dapat tumbuh dan berkembang dengan pesat.

Sistem ekonomi berdasarkan prinsip syariah tidak hanya merupakan sarana untuk menjaga keseimbangan kehidupan ekonomi, tetapi juga merupakan sarana untuk merealokasi sumber-sumber daya kepada orangorang yang berhak menurut syariah sehingga dengan demikian tujuan efisiensi ekonomi dan keadilan dapat dicapai secara bersama. ${ }^{25}$

\footnotetext{
${ }^{25}$ Fathurrahman Djamil, Hukum Ekonomi Islam, Sejarah, Teori dan Konsep, (Jakarta: Sinar Grafika, 2013), 17.
}

8 | INDO-ISLAMIKA, Volume 9 No.1 Januari-Juni 2019/1440 
Sebenarnya upaya-upaya bank syariah dalam mematuhi prinsip-prinsip syariah telah ditempuh dengan baik. Hal ini didasarkan pada regulasi-regulasi tentang kepatuhan syariah terhadap prinsip-prinsip syariah. Di antaranya adalah Undang-Undang Perbankan No. 21 Tahun 2008 Tentang Perbankan Syariah pada pasal $7^{26}$ menegaskan bahwa bank syariah adalah bank yang melaksanakan kegiatan usahanya berdasarkan prinsip syariah. Hal senada juga diatur dalam Undang-Undang No. 40 Tahun $2007^{27}$ Tentang Perseroan Terbatas pada pasal 109 bahwa: (1) Perseroan yang menjalankan kegiatan usaha berdasarkan prinsip syariah selain mempunyai Dewan Komisaris wajib mempunyai Dewan Pengawas Syariah. (2) Dewan Pengawas Syariah sebagaimana dimaksud pada ayat (1) terdiri atas seorang ahli syariah atau lebih yang diangkat oleh RUPS atas rekomendasi Majelis Ulama Indonesia. (3) Dewan Pengawas Syariah sebagaimana dimaksud pada ayat (1) bertugas memberikan nasihat dan saran kepada Direksi serta mengawasi kegiatan Perseroan agar sesuai dengan prinsip syariah. Peraturan Bank Indonesia No. 15 Tahun 2013 Tentang Bank Umum Syariah pada pasal 9 juga menjelaskan bahwa bank syariah dalam menjalankan kegiatannya harus berdasarkan prinsip syariah.

Selain itu bank syariah dalam praktiknya juga didukung oleh fatwa Dewan Syariah Nasional, Majelis Ulama Indonesia (DSN-MUI) yang membahas tentang aturan-aturan perbankan syariah, dan secara internal pengawasan juga dilakukan oleh Dewan Pengawas Syariah. Namun hal tersebut tersebut masih dirasa kurang efektif, karena bank syariah memiliki sistem yang berbeda dengan lembaga keuangan syariah lainnya dalam memerankan tugas dan fungsinya dalam mengelola dana nasabah. Usaha simpan pinjam yang identik dengan bank konvensional juga masih melekat pada bank syariah. Sehingga dalam praktik-praktik tertentu bank syariah masih menggunakan sistem dan mekanisme bank konvensional, seperti analisa kredit, tingkat kolektibilatas nasabah, sistem perhitungan bagi hasil, dan hal-hal yang terkait dengan masalah pembiayaan. Keunikan bank syariah yang secara performa masih menggunakan sebagian sistem dan aturan bank konvensional terkadang menjadi kendala tersendiri untuk menerapkan prinsip syariah secara menyeluruh. Padahal Allah subhānahu wa ta 'āla menyerukan kepada hamba-hambanya yang beriman untuk masuk ke dalam Islam secara $k \bar{a} f f \bar{a} h .^{28}$

${ }^{26}$ Undang-Undang Republik Indonesia Nomor 21 Tahun 2008, Tentang Perbankan Syariah, Pasal 7, 8 .

${ }^{27}$ Undang-Undang Republik Indonesia Nomor 40 Tahun 2007, Tentang Perbankan Syariah, Pasal 109, 42.

${ }^{28}$ Berislam secara menyeluruh yaitu menjalankan Islam berdasarkan Alquran dan alSunnah yang berdimensi dunia akhirat. Mohammad Zahid, "Islam Kaffah dan Implementasinya", Karsa, (2006), Vol. 9, No. 1, 809.

INDO-ISLAMIKA, Volume 9 No.1 Januari-Juni 2018/1440 | 9 
Tidak hanya dalam masalah, aqidah, ibadah, bahkan dalam masalah muamalah. Artinya Islam tidak hanya mengatur hubungan vertikal antara manusia dengan Sang Pencipta saja, namun juga mengatur hubungan horizontal antara manusia dengan manusia lainnya (mu'āmalah). Masalah yang terkait dengan muamalah telah diatur secara gamblang dan jelas oleh Islam, karena muamalah merupakan hal yang sangat sensitif apabila tidak diperhatikan secara serius. Seperti dalam urusan utang-piutang, syariah telah mengatur dengan tuntas, seperti harus ditulis, disaksikan dan lain-lain agar dikemudian hari tidak menimbulkan perselisihan di antara kedua belah pihak. Dan Allah subhānahu wa ta'āla juga telah menyerukan kepada hambahambanya yang beriman untuk menepati janji-janjinya.

Demikian pula yang terkait dengan jual beli dan perniagaan Islam juga telah mengaturnya dengan jelas dan gamblang, seperti halalnya jual beli, syarat dan rukun jual beli, barang-barang yang tidak boleh diperjual belikan, larangan unsur riba, gharar, maisir, memakan harta sesama dengan cara yang bathil, mengurangi takaran timbangan ketika menjual sesuatu dan minta ditambahkan takaran timbangannya ketika membeli sesuatu, dan hal-hal yang terkait dengan hal itu telah diatur dengan sempurna. Termasuk akad-akad yang digunakan dalam bermuamalah seperti, wadī'ah, qard, mushārakah, mud̄ārabah, musāqah, murābahah, salam, istiṣna' dan akad-akad lainnya. Semua telah diatur oleh syariah. Kepatuhan terhadap prinsip-prinsip syariah ini yang terkadang masih sulit diterapkan oleh bank syariah.

Berdirinya bank syariah didasarkan pada syariat Islam dan kenyataankenyataan yang ada di Indonesia, bahwa (1) masyarakat Indonesia mayoritas beragama Islam, (2) meningkatnya kesadaran umat Islam untuk melaksanakan nilai-nilai Islam sesuai ajarannya, (3) bank-bank konvensional dirasakan kurang berperan secara optimal dalam membantu memerangi kemiskinan dan memeratakan pendapatan, karena bank dengan sistem bunga tidak memberi peluang kepada orang miskin untuk mengembangkan usahanya agar lebih meningkat, (4) kebijakan pemerintah di bidang ekonomi khususnya sangat mendukung beroperasinya bank syariah, (5) wujud bank syariah sejalan dengan orientasi pembangunan nasional di Indonesia. ${ }^{29}$

Pembiayaan merupakan salah satu kegiatan bank syariah, sebagai usaha untuk memperoleh laba, tetapi rawan risiko yang tidak saja dapat merugikan bank, tetapi juga berakibat kepada masyarakat penyimpan dan pengguna dana. Oleh karena itu bank harus menerapkan fungsi pengawasan yang bersifat menyeluruh, dengan tiga prinsip utama, yaitu: prinsip pencegahan dini, prinsip pengawasan melekat, dan prinsip pemeriksaan internal. ${ }^{30}$

\footnotetext{
${ }^{29}$ Wakum Sumitro, Asas-Asas Perbankan Islam dan Lembaga-Lembaga Terkait (BAMUI \& TAKAFUL) di Indonesia, (Jakarta: Grafindo Persada, 1997), 75-76.

${ }^{30}$ Zainul Arifin, Dasar-Dasar Manajemen Bank Syariah, (Tangerang: Azkia Publisher, 2009), 257.
}

10 | INDO-ISLAMIKA, Volume 9 No.1 Januari-Juni 2019/1440 
Kepatuhan terhadap prinsip syariah (shariah compliance) merupakan prinsip utama yang sangat penting. Karena hal ini sangat menentukan dalam membangun trust (kepercayaan) kaum muslimin terhadap bank syariah. Shariah compliance menjadi furqān (pembeda) yang jelas antara bank syariah dengan bank konvensional. Penerapan shariah compliance harus didukung penuh oleh semua pihak, baik pemerintah, ulama, pelaku usaha, dan kaum muslimin secara umum. Implementasi shariah compliance di perbankan syariah di Indonesia merupakan sebuah kewajiban yang harus dilaksanakan dengan baik. Dan dalam hal ini DPS sebagai internal kontrol bank syariah tidak boleh membiarkan pelanggaran-pelanggaran syariah terjadi, karena hal tersebut secara otomatis akan merusak citra dan kredibilitas bank syariah di mata umat Islam dan masyarakat secara umum. Untuk itu peran DPS harus dioptimalkan.

Pelanggaran terhadap prinsip syariah biasanya disebabkan oleh berbagai macam faktor, di antaranya adalah kaum muslimin yang belum terbiasa untuk berbagi risiko, artinya belum siap dengan investasi yang berpotensi rugi. Harapan mereka terhadap bank syariah adalah bahwa bank syariah dapat memberikan bagi hasil yang sesuai. Hampir semua nasabah bank syariah berharap agar bank syariah menerapkan prinsip syar'i, sehingga bebas dari riba, menjadi sarana lalu lintas keuangan yang mampu mengakomodir kebutuhan nasabah dengan berbagai macam sistem perbankan yang canggih dan profesional, mengamankan uang nasabah, memberikan kontribusi bagi hasil yang signifikan, minimal sama dengan bunga pada bank konvensional, maksimal lebih besar dari itu, dan menjadi mitra UMKM (Usaha Mikro, Kecil, dan Menengah) $)^{31}$, maupun kerjasama proyek-proyek besar. Sehingga keberadaan bank syariah akan mendorong perekonomian umat dan berkontribusi terhadap pemerataan pembangunan nasional. Namun demikian harapan nasabah ini masih terlalu sulit untuk dipenuhi, hal itu dikarenakan adanya kendala-kendala secara regulasi keuangan perbankan maupun permintaan pasar yang cukup sulit untuk diakomodir.

Di satu sisi bank syariah menghimpun dana masyarakat dalam jumlah yang sangat besar, kemudian bank syariah berkewajiban memberikan bagi hasil yang yang sesuai dengan harapan nasabah, tetapi di sisi lain bank syariah harus memutar dana nasabah untuk usaha-usaha halal dan produktif dengan bekerjasama dengan perusahaan-perusahaan potensial dengan akad ijārah, murābah̆ah dan mushārakah. Bank syariah juga berusaha akan meminta bagi hasil kepada para pengelola usaha dengan jumlah di bawah bunga pembiayaan kredit bank konvensional. Sehingga dengan demikian bank syariah akan mendapatkan untung yang maksimal dari pengelola usaha, kemudian pengelola usaha juga mendapatkan manfaat dengan adanya fasilitas

\footnotetext{
${ }^{31}$ UU No. 20 Tahun 2008, Tentang Usaha Mikro, Kecil, dan Menengah, 5.
} 
pembiayaan modal kerja dan investasi sehingga dapat terus mengembangkan usahanya, dan bank syariah akhirnya mampu memberikan bagi hasil yang sesuai kepada nasabah, dan bank syariah sendiri mendapat keuntungan untuk membiayai manajemennya. Sehingga kepercayaan nasabah meningkat, bank syariah terus berkembang, usaha kecil, mikro, dan menengah semakin sehat dan bergairah, dan perekonomian umat semakin maju. Namun pada praktiknya tidak demikian. Hal tersebut masih menjadi sebuah mimpi yang harus diwujudkan secara bersama-sama.

Shariah compliance hadir untuk mendorong perbankan syariah agar mematuhi aturan syariah dengan tujuan agar bank syariah bebas riba, gharar, maisir, dan hal-hal yang menyimpang lainnya. Shariah compliance tidak bekerja untuk menilai salah dan benar bank syariah saja, tetapi bertujuan untuk memberi masukan-masukan solutif kepada bank syariah. Shariah compliance tidak hanya diterapkan di Indonesia, tetapi juga diterapkan di negara-negara lain, seperti, Malaysia, Pakistan, Yordania, London dan negara-negara yang memiliki bank syariah. Shariah compliance merupakan sebuah bentuk perhatian yang diberikan pemerintah dan masyarakat terhadap bank syariah. Audit kepatuhan terhadap bank syariah dilakukan dengan berbagai macam metode dan pendekatan yang sesuai. Objek yang diteliti dalam setiap pembahasan berbeda-beda. Mulai dari produk, jasa, dan akad bank syariah, sistem operasi bank syariah, laporan keuangan bank syariah, manajemen bank syariah, dan lain-lain yang terkait dengan aspek syariah, terutama hal-hal yang bersifat prinsipil. Setiap pembahasan tentang shariah compliance dapat memberikan kontribusi yang positif bagi bank syariah.

Urgensi kepatuhan syariah adalah untuk memitigasi risiko operasional pada bank syariah. Dan untuk lebih memperkuat sistem pengawasan internal bank syariah. Audit kepatuhan syariah senantiasa membahas halal-haram, akad, maqūṣid al-sharī'ah, dan laporan keuangan.

Produk mushārakah merupakan konsep kerjasama kemitraan dalam pembiayaan bagi hasil yang saling menguntungkan. Seharusnya akad-akad pembiayaan yang bersifat produktif seperti mushārakah dan mudārabah ini lebih diminati oleh masyarakat ketimbang akad-akad yang bersifat konsumtif seperti murābahah dan yang lainnya. Pembiayaan mushärakah memberikan benefit yang signifikan terhadap pengembangan UMKM, dapat meningkatkan taraf hidup dan ekonomi masyarakat. Sudah saatnya masyarakat diedukasi untuk hijrah pada usaha-usaha produktif. Hal ini senada dengan pendapat Ma'ruf Amin ${ }^{32}$, bahwa ada beberapa manfaat dari pembiayaan muḍārabah dan mushārakah, diantaranya adalah; (1) akan menggairahkan sektor riil, (2) dapat meningkatkan investasi, (3) terbukanya lapangan kerja baru, (4) mendorong

${ }^{32}$ Ma'ruf Amin, Prospek Cerah Perbankan Islam, (Jakarta: Lembaga Kajian Agama dan Sosial, 2007), 131. 
tumbuhnya investor, dan lain-lain. Sebab apabila kaum muslimin berkecukupan, makmur dan sejahtera niscaya hartanya akan banyak terdistribusi kepada saudara-saudaranya yang membutuhkan. Tentunya hal ini yang harus menjadi harapan dan cita-cita besar. Dibukanya kerjasama pembiayaan bagi hasil di seluruh bank syariah seharusnya menjadi angin segar bagi pengusaha muslim untuk membangun dan mengembangkan usahanya. Tetapi yang harus diperhatikan di sini adalah bahwa bank syariah dan nasabah harus sama-sama cakap hukum. Paham terhadap prinsip-prinsip syariah dalam bermuamalah. Dan usaha yang bersifat kemitraan ini juga merupakan upaya saling ber ta' 'âwun dalam kebaikan dan takwa.

Dalam melakukan kerjasama kedua belah pihak dituntut untuk memahami maquassid al-sharī 'ah yang merupakan prinsip-prinsip dasar dalam bermuamalah. Sistem perbankan yang dioperasikan oleh bank syariah juga harus dijelaskan secara detail kepada nasabah, agar mereka tahu secara persis praktik-praktik pembiayaan mushārakah yang sedang diterapkan. Sebenarnya kerjasama mushārakah secara teori dan praktik sangat sederhana. Tetapi dalam praktiknya memang harus dilengkapi lagi dengan aturan-aturan yang mengikat kedua belah pihak. Misalkan aturan yang terkait dengan laporan keuangan yang menyatakan biaya-biaya sebenarnya dapat dibatasi, karena jika estimasi suatu usaha itu berbiaya tinggi maka keuntungan yang diperoleh tentu sedikit. Untuk itu masih memungkinkan dilakukan efisiensi terhadap biayabiaya. Dan biaya-biaya itu sendiri sebenarnya merupakan beban kebutuhan dana yang harus dikeluarkan untuk memperoleh suatu keuntungan. Karena setiap usaha yang maju pasti didukung dengan biaya yang cukup. Dan hal itu kemudian tidak lantas menjadikan usaha itu bangkrut, karena telah mengeluarkan biaya-biaya, semua biaya dapat dikalkulasi, direncanakan dan dibatasi. Dan besaran biaya-biaya itu juga harus disepakati di awal perjanjian, kemudian bank syariah juga dapat membuat proporsi struktur modal yang ideal dan seimbang.

Dengan demikian konsep bagi hasil dengan sistem profit and loss sharing dapat diterapkan dalam pembiayaan mushārakah, yang mana bagi hasil dihitung dari net profit (keuntungan bersih) sehingga kedua belah pihak akan mendapatkan bagi hasil yang adil dan menentramkan karena semua modal dan biaya telah dikalkulasikan dengan baik. Adanya risiko rugi dalam suatu usaha itu sangat mungkin tetapi dapat diantisipasi, artinya laporan keuangan yang diberikan oleh pengelola usaha kepada șăhib al-māl dapat menjadi sarana evaluasi usaha, sehingga potensi keuntungan pada bulan berikutnya dapat diperkirakan, dan diprediksi.

Shariah compliance harus melihat dari seluruh sisi baik yang bersifat regulasi, sistem yang dijalankan, pendekatan halal dan haram dan maqūșid alsharī'ah sehingga permasalahan yang terjadi dapat dilihat secara utuh dan diberikan masukan yang tepat dan solusi secara tuntas, agar menjadi masukan 
yang berharga. Semangat shariah compliance harus terus didukung, didorong, dan dikawal secara ketat untuk memperoleh kualitas pelayanan perbankan yang sesuai dengan prinsip-prinsip syariah. Ketidakpatuhan terhadap pemenuhan prinsip-prinsip syariah akan menjadikan bank syariah melenceng dan terjebak pada praktik-praktik riba, gharar, dan maisir yang menggelisahkan dan mengkhawatirkan.

\section{A. Konsep Shariah Compliance}

\section{Teori Shariah Compliance}

\section{a. Shariah Compliance}

Shariah Compliance (kepatuhan terhadap syariah) adalah suatu bentuk perilaku yang mencerminkan bahwa sebuah lembaga keuangan syariah harus memenuhi (comply) prinsip-prinsip syariah dalam menjalankan kegiatan usahanya. Kepatuhan terhadap prinsip syariah tidak hanya berlaku pada akad dan produk lembaga keuangan syariah saja, tapi berlaku juga pada proses operasionalisasinya. ${ }^{33}$ Shariah compliance secara eksplisit atau implisit memainkan peran yang sangat penting dalam pengawasan Lembaga Keuangan Islam. ${ }^{34}$ Shariah compliance berarti mematuhi semua aturan yang terdapat dalam Alquran dan al-Sunnah. ${ }^{35}$ Sebastian Partogi mengatakan bahwa: "Patuh terhadap aturan syariah adalah kunci utama keunggulan bank syariah". ${ }^{36}$

Lebih lanjut Beliau mengatakan bahwa pengaturan dan pengawasan syariah pada perbankan syariah merupakan dua hal yang sangat penting untuk meyakinkan masyarakat bahwa seluruh transaksi dan operasi yang dijalankan sudah sesuai dengan syariah. Bank Syariah harus secara ketat mematuhi prinsip-prinsip syariah, karena hal itu adalah satu-satunya jalan untuk menjaga kepercayaan dan harapan nasabah. ${ }^{37}$ Para ulama klasik berpendapat bahwa kepatuhan terhadap prinsip syariah

\footnotetext{
${ }^{33}$ Volker Nienhaus, "Islamic Finance Ethics and Shariah Law In The Aftermath of The Crisis: Concept and Practice of Shariah Compliant Finance", International Journal, Ethical Perspective, Vol. 18, No. 2 (2011): 592.

${ }^{34}$ Inwon Song - Carel Oosthuizen, "Islamic Banking Regulation and Supervision: Survey Result and Callenges", IMF Working Paper, Monetary and Capital Market Departmen, (2014): 13.

${ }^{35}$ Ruma Hanam - Hafij Ullah, "Shariah Compliance In Islamic Banking Why and How?", Global Journal an Management and Bussines Research C Finance, Vol. 14, No. 1 (2014): 3.

${ }^{36}$ Sebastian Partogi, "Compliance With Sharia A Key Advantage of Islamic Banking”, The Jakarta Post, (2014): 11:42 am.

${ }^{37}$ Zainurin Dahari, "Measuring Service Quality In Islamic Banking: Importance Performance Analysis Approach", Asean Journal of Bussines Research, Vol. 5, No. 1 (2015), 26.
} 
bagi lembaga keuangan Islam menjadi barometer keabsahan bagi seluruh transaksi keuangan yang dijalankan. ${ }^{38}$ Karena lembaga keuangan Islam merupakan segmen yang tumbuh paling cepat dalam isu keuangan Islam global, sehingga kepatuhan terhadap prinsip syariah dalam transaksi keuangan harus menjadi sistem yang melekat kuat untuk membentengi virus riba, gharar, dan maisir. ${ }^{39}$ Penegasan larangan riba harus dikuatkan di setiap bank syariah. ${ }^{40}$ Shariah compliance harus memastikan bahwa bank syariah benar-benar taat dan patuh terhadap aturan Islam dan bank syariah harus benar-benar bebas dari riba. ${ }^{41}$ Yang dimaksud dengan prinsip syariah adalah prinsip hukum Islam yang digunakan dalam melaksanakan kegiatan usaha, seperti akad kerjasama mushārakah, mud̄ārabah, murābahah, dan lain-lain. Akad-akad tersebut harus sesuai dengan prinsip syariah yang berindikasikan bersih dari riba, gharar, dan maisir.

Prinsip syariah menjamin kerjasama yang dilakukan oleh kedua belah pihak atau lebih terbebas dari perbuatan yang haram. Prinsip syariah dalam dunia bisnis merupakan salah satu tujuan syariah (maqāșid al-sharī'ah) itu sendiri, yaitu hiffz al-māl (penjagaan terhadap harta). Unsur utama (darūriyyāt) dalam memperoleh harta adalah dengan menggunakan syariat Islam. Islam mengatur secara rinci dan gamblang tentang kepemilikan harta. Tentang persoalan harta seorang hamba akan ditanya tentang dua hal, dari mana ia mendapatkan harta itu, dan dibelanjakan untuk apa. ${ }^{42}$ Pada pembahasan ini yang digarisbawahi adalah bagaimana cara memperoleh harta yang sesuai dengan syariah.

Pada perbankan syariah seseorang itu bisa mendapatkan harta dengan cara berinvestasi atau kerjasama pembiayaan bisnis. Diantara

${ }^{38}$ Sana N. Maswadeh, "A Compliance of Islamic Banks with The Principles of Islamic Finance (Shariah): An Empirical Survey of The Jordanian Bussines Firm”, International Journal of Accounting And Financial Reporting, (2015): Vol. 4, No. 1, 173.

${ }^{39}$ Alsadek Hesein, A. Gait, "The Impact of Demographic Variables On Libyan Retail Consumers' Attitudes Towards Islamic Methods of Finance", Islamic Economic Studies, (2009): Vol. 17, No. 1, 1.

${ }^{40}$ Saduman Okumus, "Interest Free Banking In Turkey: A Study of Customer Satisfaction And Bank Selection", Department of Banking and Finance, Istanbul Commerce University, Turkey, European Scientific Journal, (2013): Vol. 9, No.16, 145.

${ }^{41}$ Aziza Naz and Awais Farooq, "Customer Petronage in Selection Criteria of Islamic Bank in Pakistan”, The International Journal Bussines and Management, Vol. 4 No. 10, 2016, 363.

${ }^{42}$ Lihat HR al-Tirmidhi, No. 2417, al-Dārimi No. 537, dan Abu Ya‘la No. 7434, dishahihkan oleh al-Tirmidhi dan al-Albāni dalam "al- Șaḥịhah" No. 946 karena banyak jalurnya yang saling menguatkan, https://muslim.or.id/3952-mengatur-dan-membelanjakanharta.html, Abdullah Taslim, Mengatur dan Membelanjakan Harta, diunduh pada hari Rabu, 29 Maret 2009. 
bentuk investasi adalah dengan menggunakan fasilitas tabungan mudārabah atau deposito. Dan dalam kerjasama bisnis bisa menggunakan fasilitas pembiayaan dengan akad pertukaran atau jual beli (murābahah, istișna', dan salam), percampuran atau shirkah (mushārakah dan mud̄̄abah), dan sewa (ijārah dan ijārah muntahiya bi al-tamlīk).

Investasi dan kerjasama bisnis yang dilakukan akan menghasilkan keuntungan yang berimplikasi pada nilai-nilai keadilan, kemakmuran, dan keberkahan dunia dan akhirat. Untuk itu kepatuhan terhadap prinsip syariah harus dijalankan dengan baik dan benar. Karena kepatuhan terhadap prinsip syariah akan berimplikasi pada kepercayaan dan keyakinan. Sebuah lembaga keuangan syariah yang patuh terhadap prinsip syariah akan menjadi sentral ekonomi dan bisnis kaum muslimin dan masyarakat secara luas. Dan shariah compliance merupakan salah satu pilar yang membedakan antara lembaga keuangan syariah dengan lembaga keuangan konvensional. ${ }^{43}$

\section{b. Dasar Shariah compliance}

Prinsip syariah dalam teori ekonomi Islam pada dasarnya memiliki tiga ciri yang mendasar: (1) Prinsip keadilan, (2) Menghindari aktivitas ekonomi yang dilarang, dan (3) Memperhatikan aspek kemanfaatan. ${ }^{44}$ Ketiga ciri tersebut tidak hanya sebatas pada teori belaka, namun bisa dirasakan secara langsung oleh siapapun yang terlibat dalam kegiatan ekonomi Islam. Untuk memastikan ketiga hal tersebut maka perlu dibuatkan standar produk perbankan syariah dalam berbagai akad oleh lembaga yang memiliki kapasitas untuk itu, agar menjadi panduan dalam kerjasama investasi dan pembiayaan. Dalam hal ini keterlibatan Majelis Ulama Indonesia dalam menentukan arah perbankan syariah di Indonesia menjadi sangat vital. Karena MUI harus membuat fatwa-fatwa terkait hukum ekonomi Islam yang digunakan dalam perbankan syariah, sekaligus mengawasi proses kepatuhan bank syariah terhadap fatwa Dewan Syariah Nasional (DSN) MUI, agar seluruh proses transaksi yang dijalankan sesuai dengan syariah.

c. Urgensi dan Manfaat Shariah Compliance Pada Perbankan Syariah di Indonesia.

Sistem ekonomi bebas riba sesungguhnya telah dijalankan ketika riba pertama kali dilarang di wilayah Arab. Maududi meyakinkan bahwa

\footnotetext{
${ }^{43}$ http://www.agustiantocentre.com/?p=72, Agustianto, Pentingnya Shariah compliance, diunduh pada hari Kamis, 16 Februari 2017.

${ }^{44}$ Zainuddin Ali, Hukum Perbankan Syariah, (Jakarta: Sinar Grafika, 2010), Cet. 2, 20.
} 
tidak ada kesulitan sedikitpun dalam mencapai tujuan ini. ${ }^{45}$ Alasannya bahwa utang tidak boleh mengambil bunga tetap kepada orang yang diberi pinjaman. Dan utang-piutang itu sendiri sama sekali tidak terkait dengan untung rugi. Sehingga jelas dan terang-benderang bahwa bunga (riba) tidak bisa dibuktikan kebenarannya. Dan adanya bunga akan menimbulkan ketidakadilan dan pemerasan.

Para ulama mazhab telah bersepakat bahwa bunga dengan segala macam bentuknya adalah haram. ${ }^{46}$ Tidak ada lagi perdebatan antara bunga rendah dan bunga tinggi. Namun demikian peran pemerintah harus dominan dalam memimpin perekonomian Islam yang adil dan sejahtera. ${ }^{47}$ Karena kurangnya dukungan kuat dari pemerintah maka ekonomi Islam akan sulit untuk diwujudkan, hal tersebut seperti yang terjadi pada negara-negara lain.

Bank syariah dengan konsep bagi hasil dan bebas riba merupakan isu global yang terus berkembang. Keberadaan bank Islam menjadi solusi bagi kaum muslimin untuk melakukan transaksi yang halal dan penuh berkah. Kegelisahan umat Islam dengan maraknya bank konvensional yang menerapkan bunga akhirnya terjawab sudah, dengan lahirnya bankbank syariah yang tumbuh secara terus-menerus. Pertumbuhan bank syariah di Indonesia cukup menggembirakan. ${ }^{48}$ Walaupun bank-bank syariah yang ada belum $100 \%$ sesuai dengan syariah. Bank syariah masih mengalami kendala-kendala dalam melaksanakan prinsip-prinsip syariah. Hal itu terjadi karena market share bank syariah masih belum siap untuk berbagi risiko dalam berinvestasi. Tetapi secara bertahap namun pasti bank syariah terus berusaha semaksimal mungkin untuk menerapkan prinsip syariah.

Kepatuhan terhadap prinsip syariah merupakan hal yang sangat urgen. Karena hal tersebut secara teknis akan menuntun bank syariah kepada transaksi ekonomi yang adil dan berkah, yang mengantarkan pelakunya mendapatkan keberuntungan dunia dan akhirat.

Urgensi kepatuhan syariah adalah memastikan hal-hal berikut ini:

${ }^{45}$ Euis Amalia, Sejarah Pemikiran Ekonomi Islam Dari Masa Klasik Hingga Kontemporer, (Depok: Gramata Publishing, 2010), 280-281.

${ }^{46}$ M. Umer Chapra, Masa Depan Ilmu Ekonomi, Sebuah Tinjauan Islam (Terj. The Future of Economics an Islamic Perspective), Sebuah Tinjauan Islam, (Jakarta: Gema Insani Press bekerjasama dengan Tazkia Cendekia, 2001), Cet. 1, 222.

${ }^{47}$ M. Umer Chapra, Islam dan Pembangunan Ekonomi (Terj. Islam and Economic Development), (Jakarta: Gema Insani Press bekerjasama dengan Tazkia Institute, 2000), Cet. 1,60 .

${ }^{48}$ http://www.bi.go.id/id/statistik/perbankan/syariah/Default.aspx,,$\quad$ Statistik Perbankan Syariah, diunduh pada hari Rabu, 29 Maret 2017. 
1) Bahwa setiap akad yang dijalankan oleh bank syariah, harus sesuai dengan akad yang telah difatwakan oleh DSN-MUI. ${ }^{49}$

2) Bahwa setiap transaksi yang dilakukan oleh bank syariah tidak mengandung unsur riba, gharar, maisir, haram, dan zalim.

Pelarangan riba diharapkan bisa mendorong terbentuknya kecenderungan masyarakat untuk tidak bersikap memastikan, dan berubah berani menghadapi risiko. ${ }^{50}$ Maisir mengakibatkan orang berpikir spekulasi, memperoleh keuntungan dengan sangat mudah tanpa adanya kerja keras. ${ }^{51}$ Larangan maisir juga tercermin dari kegiatan bank yang melarang investasi yang tidak terkait dengan sektor riil. Hal ini juga akan membentuk kondisi masyarakat untuk tidak berspekulasi dalam berinvestasi. Sedangkan gharar menghendaki transparansi (keterbukaan) dan kejelasan, untuk itu dalam setiap kerjama bisnis mewajibkan pencatatan yang baik dan rapi, hal itu untuk menghindari perbedaan persepsi atau silang sengketa di kemudian hari. Haram untuk memastikan bahwa objek yang dijadikan transaksi adalah halal, dan haram secara umum untuk menghindari larangan-larangan yang ditetapkan oleh Allah subhāanahu wa ta 'àla dan Rasul-Nya. Zalim untuk menghindari ketidakadilan atau perlakuan tidak adil dalam bisnis.

Dengan mengetahui urgensi ini maka masyarakat yang bergabung dengan bank syariah akan merasakan kenyamanan dan ketentraman. Rasa nyaman dan tentram merupakan hak nasabah yang harus terus dijaga oleh bank syariah. Sehingga hubungan partnership itu akan berkelanjutan sampai dalam jangka waktu yang panjang. Ketika bank syariah tumbuh, maka sektor riil akan bergairah, usaha mikro, kecil, dan menengah akan tumbuh, dan pemerataan distribusi pendapatan akan terjadi, dan secara tidak langsung perekonomian nasional akan terus merangkak naik.

\section{Konsep Shariah Compliance Pada Bank Syariah}

Kepatuhan bank syariah terhadap prinsip syariah merupakan amanah UU No. 21 Tahun 2008 Tentang Perbankan Syariah. ${ }^{52}$ Prinsip syariah menjadi ciri utama bank syariah, dan prinsip syariah juga menjadi alasan utama umat Islam dalam menentukan pilihan bergabung pada bank syariah, baik dalam kapasitasnya sebagai șạhib al-māl (investor) maupun sebagai

\footnotetext{
${ }^{49}$ Lihat kewenangan MUI dalam penjelasan UU No. 21 Tahun 2008 Tentang Perbankan Syariah, yang menjelaskan tentang implementasi kepatuhan syariah.

${ }^{50}$ Khotibul Umam, Perbankan Syariah, Dasar-Dasar dan Dinamika Perkembangannya di Indonesia, (Jakarta: Raja Grafindo Persada, 2016), Cet. 1, 192.

${ }^{51}$ Ascarya, Akad \& Produk Bank Syariah, (Jakarta: Raja Grafindo, 2007), 20.

${ }^{52}$ UU No. 21 Tahun 2008 Tentang Perbankan Syariah, Pasal 1 Ayat 7.
} 
muḍāib (pengelola usaha). Prinsip syariah menjamin bahwa setiap transaksi dan operasi yang dilakukan oleh perbankan syariah sesuai dengan ketentuan syariah, dan bebas dari unsur riba, gharar dan maisir. Oleh karena itu kepatuhan terhadap prinsip syariah wajib dilaksanakan.

Perbankan syariah di Indonesia memiliki aturan-aturan yang memadai dalam menjalankan prinsip syariah. Di antaranya adalah UU No. 21 Tahun 2008 tentang perbankan syariah. ${ }^{53}$ Dalam undang-undang ini secara khusus juga dijelaskan bahwa kepatuhan bank syariah terhadap prinsip syariah telah diatur secara rinci. Majelis Ulama Indonesia (MUI) telah diberi kewenangan secara penuh untuk merumuskan pelaksanaan shariah compliance yang direpresentasikan melalui Dewan Pengawas Syariah (DPS). DPS harus dibentuk di setiap bank syariah untuk memastikan implementasi shariah compliance berjalan dengan baik pada setiap bank syariah.

\section{B. Prinsip Keadilan dan Kepatuhan Syariah}

Yang dimaksud dengan prinsip keadilan dalam pembahasan ini adalah prinsip keadilan dalam kerjasama mushārakah. Prinsip keadilan dalam kerjasama mushārakah pada masa klasik di antaranya adalah bahwa kedudukan masing-masing mitra dalam kerjasama ini (shärik) sejajar, walaupun porsi modal masing-masing mitra tidak sama. Masing-masing mitra memiliki tujuan dan kepentingan yang sama dan keduanya saling membutuhkan antara yang satu dengan yang lainnya. Kerjasama mushārakah ini merupakan kemitraan aktif.

Masing-masing mitra, aktif dalam mengelola usaha secara bersama-sama. Satu sama lain saling bahu-membahu untuk mewujudkan tujuan dalam kerjasama ini yaitu memperoleh keuntungan sesuai dengan yang diharapkan oleh masing-masing mitra. Semangat kebersamaan dan kemitraan aktif yang dibangun di atas moral dan persaudaraan dalam kerjasama mushārakah ini akan memupuk kepercayaan dan solidaritas yang kuat di antara keduanya. Kemudian konsep bagi hasil dan kerugian dipraktikkan dengan benar dan disepakati di awal akad. Jika usaha yang dijalankan mendapatkan keuntungan maka keuntungan tersebut dibagi sesuai dengan porsi bagi hasil yang disepakati oleh kedua belah pihak. Jika untungnya kecil maka nilai bagi hasilnya juga kecil, jika keuntungannya besar maka nilai bagi hasilnya juga besar. Jika usaha yang dijalankan tidak memperoleh keuntungan maka keduanya sama-sama tidak mendapatkan bagi hasil, dan jika usaha yang dijalankan rugi maka kerugian tersebut ditanggung bersama oleh masing-masing mitra berdasarkan

${ }^{53}$ UU No. 21 Tahun 2008 Tentang Perbankan Syariah, Pasal 51 Ayat 1, Bahwa bank syariah harus patuh terhadap prinsip syariah dan prinsip manajemen yang Islami dalam menjalankan usahanya.

INDO-ISLAMIKA, Volume 9 No.1 Januari-Juni 2018/1440 | 19 
porsi modal yang dikontribusikan. Dan kerjasama mushārakah yang dijalankan tidak mengandung unsur riba, gharar, maisir, haram, dan zalim seperti kerjasama-kerjasama lainnya secara umum.

Dengan demikian dapat disimpulkan bahwa unsur-unsur prinsip keadilan dalam kerjasama mushārakah adalah bahwa kedudukan masing-masing mitra sejajar, terwujudnya kemitraan aktif, adanya semangat kebersamaan yang dibangun di atas moral dan persaudaraan, terwujudnya praktik bagi untung-dan bagi rugi dengan benar, dan terhindar dari prinsip-prinsip muamalah yang dilarang dalam Islam. Sehingga dengan demikian tidak ada pihak yang mengeksploitasi dan dieksploitasi.

Adapun konsep mushārakah di bank syariah berbeda dengan konsep mushārakah pada masa klasik. Konsep mushārakah di bank syariah telah direduksi oleh fatwa DSN-MUI yang berimplikasi pada pergeseran. Pergeseran yang terjadi adalah bahwa kedudukan nasabah pembiayaan mushārakah seolah-olah tidak sejajar dengan bank syariah. Nasabah lebih membutuhkan bank syariah untuk memenuhi kebutuhan modal usahanya, dan karena kerjasama ini berisiko tinggi maka bank syariah menetapkan expected rate bank-nya juga tinggi. Kesan utang-piutang dalam kerjasama mushārakah masih kuat. Kemudian kemitraan aktif tidak dapat diterapkan, hal itu disebabkan karena bank syariah sebagai lembaga keuangan pada dasarnya tidak diperbolehkan terjun langsung ke sektor riil, atau bergabung dengan nasabah dalam satu manajemen usaha. Jadi bank syariah dalam kerjasama ini hanya sebagai mitra pasif.

Kemitraan pasif ini mengandung kelemahan-kelemahan yang berimplikasi pada ketidakjujuran, kecurigaan, dan lain-lain. Kemudian metode bagi hasil yang diterapkan oleh bank syariah adalah revenue sharing, metode ini lebih menguntungkan pihak bank ketimbang nasabah. Dan jika metode ini diterapkan maka ada bagi untung tetapi tidak ada bagi rugi. Metode bagi hasil yang diterapkan oleh bank syariah cenderung tidak adil. Kemudian bank syariah menerapkan sanksi denda dan ganti rugi, dan biaya administrasi yang berpotensi mengandung riba.

Untuk itu penulis telah mengukur unsur-unsur kedilan tersebut pada standar produk mushārakah dan pelaksanaan produk mushārakah di Bank Syariah Mandiri. Unsur-unsur yang diukur adalah; standar manajemen usaha, standar bagi hasil dan kerugian, standar denda dan ganti rugi, dan standar biaya. Empat hal inilah yang

digali dan diuji oleh penulis. Apakah keempat unsur tersebut sesuai dengan prinsip keadilan atau tidak.

Sedangkan kepatuhan syariah adalah menjelaskan tentang konsep dan implementasi kepatuhan syariah yang dilaksanakan oleh DPS berdasarkan undang-undang, Fatwa DSN-MUI, peraturan bank Indonesia dan peraturan OJK. Objek kepatuhan syariah dalam produk mushārakah ada dua, yaitu 
kesesuaian kerjasama yang dilakukan berdasarkan Fatwa DSN-MUI dan ada tidaknya laporan usaha nasabah dan laporan keuangan nasabah yang dijadikan dasar untuk menentukan nilai bagi hasil.

Prinsip keadilan dan kepatuhan syariah bertujuan untuk menguji apakah produk mushārakah di Bank Syariah Mandiri adil dan patuh syariah atau tidak. Prinsip keadilan dalam kerjasama pembiayaan mushārakah bank syariah telah terkonseptualisasi dengan aturan-aturan yang mapan, sedangkan konsep dan implementasi kepatuhan syariah telah diatur sedemikian rupa sehingga perlu dijelaskan secara detail dan gamblang berdasarkan argumentasi-argumentasi yang terdapat dalam data primer dan skunder yang harus dipecahkan. Prinsip keadilan dan kepatuhan syariah dijelaskan untuk menunjukkan arah penelitian ini.

\section{DAFTAR PUSTAKA}

Alim, Muhammad Nizarul, Muhasabah Keuangan Syariah, (Solo: Aqwam Media Profetika, 2011).

Ali, Zainuddin, Hukum Perbankan Syariah, (Jakarta: Sinar Grafika, 2010), Cet. 2, 20.

Amalia, Euis, Sejarah Pemikiran Ekonomi Islam Dari Masa Klasik Hingga Kontemporer, (Depok: Gramata Publishing, 2010), 280-281.

Amin, Ma'ruf, Prospek Cerah Perbankan Islam, (Jakarta: Lembaga Kajian Agama dan Sosial, 2007).

Antonio, Muhammad Syafii, Bank Syariah dari Teori ke Praktik, (Depok: Gema Insani-Tazkia Cendekia, 2015).

Ascarya, Akad \& Produk Bank Syariah, (Jakarta: Raja Grafindo, 2007),

Arifin, Zainul, Dasar-Dasar Manajemen Bank Syariah, (Tangerang: Azkia Publisher, 2009).

Bali, Wāḥid Abd al-Salam, Dialog Ilmiah Bank Syariah Vs Bank Konvensional, (Jakarta: Darul Falah, 2002).

Bukhary, Abū Abdillāh Muḥammad Ibn Ismā '̂̀l al-, Șahīh al-Bukhārī, Kitāb al-İmān, Bāb Faḍlu Man-Istabra'a li Dīnihī, (Kairo: Dār al-Ghad alJadīd, 2009), Nomor Hadìth 52, 21.

Chapra, M. Umer, Masa Depan Ilmu Ekonomi, Sebuah Tinjauan Islam (Terj. The Future of Economics an Islamic Perspective), Sebuah Tinjauan Islam, (Jakarta: Gema Insani Press bekerjasama dengan Tazkia Cendekia, 2001), Cet. 1.

Choir, Wasilul, "Riba dalam Perspektif Islam", Iqtishadia, (2014), Vol. 1, No.1, 6.

Djamil, Fathurrahman, Hukum Ekonomi Islam, Sejarah, Teori dan Konsep, (Jakarta: Sinar Grafika, 2013), 17. 
Farooq, Aziza Naz and Awais, "Customer Petronage in Selection Criteria of Islamic Bank in Pakistan", The International Journal Bussines and Management, Vol. 4 No. 10, 2016.Maswadeh, Sana M, “A Compliance of Islamic Banks with The Principles Of Islamic Finance (Shariah): An Empirical Survey Of The Jordanian Business Firms", International Journal of Accounting and Financial Reporting, (2014), Vol. 4, No.1.

Jauhar, Ahmad Al-Mursi Husain r, Maqāsid al-Sharı̄'ah, (Jakarta: Sinar Grafika Offset, 2010)..

Lewis, Mervin K. Lewis - Latifa M. Algaoud, Perbankan Syariah, Prinsip, Praktik, dan Prospek, (Jakarta: Serambi, 2007), Cet.1.

Muhamad, Teknik Perhitungan Bagi Hasil dan Pricing di Bank Syariah, (Yogyakarta: UUI Press, 2012).

Nienhaus, Volker, "Islamic Finance Ethics and Shariah Law In The Aftermath of The Crisis: Concept and Practice of Shariah Compliant Finance", International Journal, Ethical Perspective, Vol. 18, No. 2 (2011).

Sawat, Ahmad, Bank Syariah Sama Saja Dengan Bank Konvensional, Benarkah?, Mon 4 November 2013 01:40 | muamalat | 62.680 views, diunduh hari Sabtu, 11 Juni 2016.

Sumitro, Wakum, Asas-Asas Perbankan Islam dan Lembaga-Lembaga Terkait (BAMUI \& TAKAFUL) di Indonesia, (Jakarta: Grafindo Persada, 1997).

http://kmi-s.ppisendai.org/bank-syariah/, Bank Syariah: Apakah Benar-benar Syar'i?, Muhammad Rifqi, diunduh hari Sabtu, 11 Juni 2016.

http://mysharing.co/dana-non-halal-untuk-fikih-islam/, Pengelolaan Dana Non Halal untuk Pemberdayaan Masyarakat Menurut Fikih Islam, by Ibrahim Aji on 20/08/2014, diunduh hari Sabtu, 11 Juni 2016.

Fatwa Dewan Syari'ah Nasional Nomor 54/DSN-MUI/X/2006 Tentang Syariah Card.

Revenue sharing adalah perhitungan bagi hasil didasarkan kepada total seluruh pendapatan yang diterima sebelum dikurangi biaya-biaya yang telah dikeluarkan untuk memperoleh pendaptan tersebut.

PBI No. 10/18/PBI/2008 Tentang Restrukturisasi Pembiayaan Bagi Bank Umum Syariah dan Unit Usaha Syariah.

Tarmidzi, Erwandi, Harta Haram Muamalat Kontemporer, (Bogor: Berkat Mulia Insani, 2015), Cet. 9.

Tirmidhi, Abū 'Īsā Muḥammad Ibn 'Īsā al-, Jāmi 'al-Tirmidhī, Kitāb șifāt alQiyāmah wa al-Raqāiq wa al-Wara', Bāb fì al-Qiyāmah, (Riyāḍ: Dār al-Salām Li al-Nashri wa al-Tauzī‘i, 1999), Nomor Ḥad̄̄th 2417.

Umam, Khotibul, Perbankan Syariah, Dasar-dasar dan Dinamika Perkembangannya di Indonesia, (Jakarta: Raja Grafindo Persada, 2016). Mohammad Zahid, "Islam Kaffah dan Implementasinya", Karsa, (2006), Vol. 9, No. 1, 809 . 
UU No. 20 Tahun 2008, Tentang Usaha Mikro, Kecil, dan Menengah

Volker Nienhaus, "Islamic Finance Ethics and Shariah Law In The Aftermath of The Crisis: Concept and Practice of Shariah Compliant Finance", International Journal, Ethical Perspective, Vol. 18, No. 2 (2011).

Inwon Song - Carel Oosthuizen, "Islamic Banking Regulation and Supervision: Survey Result and Callenges", IMF Working Paper, Monetary and Capital Market Departmen, (2014).

Ruma Hanam - Hafij Ullah, "Shariah Compliance In Islamic Banking Why and How?", Global Journal an Management and Bussines Research C Finance, Vol. 14, No. 1 (2014).

Sebastian Partogi, "Compliance With Sharia A Key Advantage of Islamic Banking", The Jakarta Post, (2014).

Zainurin Dahari, "Measuring Service Quality In Islamic Banking: Importance Performance Analysis Approach", Asean Journal of Bussines Research, Vol. 5, No. 1 (2015).

Sana N. Maswadeh, "A Compliance of Islamic Banks with The Principles of Islamic Finance (Shariah): An Empirical Survey of The Jordanian Bussines Firm”, International Journal of Accounting And Financial Reporting, (2015): Vol. 4, No. 1.

Alsadek Hesein, A. Gait, "The Impact of Demographic Variables On Libyan Retail Consumers' Attitudes Towards Islamic Methods of Finance", Islamic Economic Studies, (2009): Vol. 17, No. 1.

Saduman Okumus, "Interest Free Banking In Turkey: A Study of Customer Satisfaction And Bank Selection", Department of Banking and Finance, Istanbul Commerce University, Turkey, European Scientific Journal, (2013): Vol. 9, No.16.

Abdullah Taslim, Mengatur dan Membelanjakan Harta, diunduh pada hari Rabu, 29 Maret 2009.

http://www.bi.go.id/id/statistik/perbankan/syariah/Default.aspx,

Statistik

Perbankan Syariah, diunduh pada hari Rabu, 29 Maret 2017.

Khotibul Umam, Perbankan Syariah, Dasar-Dasar dan Dinamika Perkembangannya di Indonesia, (Jakarta: Raja Grafindo Persada, 2016), Cet. Zulkifli, Sunarto, Panduan Praktis Transaksi Perbankan Syariah, (Jakarta: Zikrul, 2007).

Undang-Undang Republik Indonesia Nomor 21 Tahun 2008, Tentang Perbankan Syariah, Pasal 7, 8.

Undang-Undang Republik Indonesia Nomor 40 Tahun 2007, Tentang Perbankan Syariah, Pasal 109, 42.

UU No. 21 Tahun 2008 Tentang Perbankan Syariah, Pasal 1 Ayat 7.

UU No. 21 Tahun 2008 Tentang Perbankan Syariah. 
Sujian Suretno

24 | INDO-ISLAMIKA, Volume 9 No.1 Januari-Juni 2019/1440 